\title{
IMPROVING THE LISTENING COMPREHENSION TO THE SECOND SEMESTER STUDENTS OF ACCOUNTING DEPARTMENT IN ECONOMIC FACULTY BY USING DICTOGLOSS TECHNIQUE
}

\author{
Nasrullah $^{1}$ \\ nasrullahumpar@gmail.com \\ University of Muhammadiyah Parepare
}

\begin{abstract}
This study examined the effect dictogloss technique in improving the listening comprehension. Dictogloss comes from two words, they are dictation and glosary. Beside that, dictogloss is a technique in which the teacher reads a short text and the learners make brief notes and then try to reconstruct the text in groups. The populations of this research are the second semester of accounting department Academic Years 2015/2016 in which the number of population are 280 students. Because of the population is too large, the researcher used cluster random sampling. This research used quasy experimental with control cass and experimental class. This research also use the pre test and post test find out the different between the class with teach by dictogloss technique and teach by conventionl methode. In this technique, the students teach by using multi media. So, the students listen from the speaker about the materials. But, before come to listening the teacher give explanation and describe about the materials that will teach then the students try to predict what kind of the materials. In this method there are some stages, they are; preparing, dictation, reconstructions, analysis and correction. Based on the research findings, most of the students enjoy and like with this methode because they can find out more new words. The data research show that null hypothesis was rejected and then the alternatife hypothesis was accepted.
\end{abstract}

Keywords: Dictation, Glosary and Listening comprehension

\section{INTRODUCTION}

Listening is one of the four skills that the students learn. Because we can not communicate with other people if we our listening low. And in listening, we need to concentrate and pay attention to speaker to get information. But most of the students low in listening because they lost the information that people say. In teaching listening sometimes the students are bored because the method is not interested for them. Beside that, the motivation of students to learn about listening still low. This is makes the researcher give one technique to teach listening, that is dictogloss. 
By this condition, the researcher wants to improve the listening comprehension by using dictogloss technique. Dictogloss is a technique that the students try to write the words that they hear from the tape recorder or from the . In dictogloos technique, the students will arrange, retell and complete the paragraph.

The researcher has conducted survey to the Second semester students of Accounting Department in Economic Faculty By interview, their lecturer said that the skills of the students are very low in listening. Beside that, from the test the students gets mean score in reading 80,84 , writing 75,19, speaking 75,57 and listening 60,29. Therefore, the researcher focuses his attention to teaching listening comprehension to the Second semester students of Accounting Department in Economic Faculty by using Dictogloss technique. So that the researcher take a title "Improving the Listening Comprehension to the Second Semester Students of Accounting Department in Economic Faculty by Using Dictogloss Technique"

\section{REVIEW LITERATURE}

\section{a. Definition of listening}

Listening skill is activity of paying attention to and trying to get meaning from we hears. To listen successful to spoken language, we need to be able to work out what speaker mean when they use particular words in particular ways on particular occasions and not simply to understand to work them. (Underwood, 1990:1 in Endang).

Will (1981:135) in Endang (2003) stated that listening is receptive rather than productive, but it is equally important skill. Students need to learn how to listen and to get the chance to listen to different types of English. So they will be able to listen with understanding to spoken English outside the classroom. According to Grolier Webster (1975:557) listening is to give close attention in other to hear into attend.

Yayang in Saricoban (1999:1) defines that listening in ability to identify and understood what other saying. It is involves understanding speaker accent and pronunciation, its grammar and vocabulary, grasping her or his meaning.

From the definition above, the researcher conclude that listening is an ability to understand and to get information from what the other people say.

\section{b. Teaching listening}

There are three main procedures in teaching listening, pre-listening stage, while listening and post-listening stage.

1) Pre-listening Stage

This stage where students do some activities before they listen text. Underwood (1990:3) in Endang state that if unfair to plunge the students straight into the listening text, even when listening rather than teaching listening ability skills (which we all use in our native language) or matching what they heard and use their previous knowledge to make sense of it. Therefore, before listening the students should be "tuned in" so that they know what to expect, both in general and for particular task. 
There are fourteen of activities that can be used in the pre-listening stages as follows:

a. Looking at the list of items/though etc

b. This type of activity is particularly helpful for practicing newly learned vocabulary with early learners. The list should have some purpose of its own in the total listening activity

c. Making lists of possibility/ideas/suggestions

d. When a listening text contains lists event short lists or of possibilities, ideas, suggestion it's often a good idea to use list making as the prelistening activity and then the students can use their own lists as the basic for a while listening activity

e. Reading a text before listening

f. Students can be ask to read a text before listening and then to check certain fact while listening

g. Reading though question (to be answered while listening)

h. Completing past of a chart

i. This activity can get the students involved in a personal way if they are invited to fill in their own views, segments or preferences

j. Redacting/speculating

k. Students can be told something about the speakers and the topic and then ask to suggest what they are likely to hear in the listening text

1. Previewing the language will be heard in the listening text

$\mathrm{m}$. A listening may sometimes provide a good example of use of particular language forms in an authentic situation and which the wants to use because his or her class has recently studied there forms

n. In formal talk and class discussion generally gives their students some background information, begin to talk about the topic and indicate what the students should expect to hear.

2) The while listening stage

Endang (2003) and Jailani (2011) The while listening stage where the students are ask to do some activities during the time that the students are listening to the text. The purpose of the while listening activities is to help the learners develop the skill electing message from the spoken language.

a) Carrying out an action. The instructed the class to do series of action they can be more interesting by turning up into some short of game

b) Making models/arranging items in patterns. The can give instruction him/herself or play a tape and the students must try to productive the model/pattern

c) Following route. The gives the students a map that corers a small area uses a rood names are easily recognize and a small number of features marked on it

d) Completing grids. The can provided or ask students to raw a grid e.g. a bloc, of boxes with each column and raw labeled 
e) Form/chart completion. The students are ask to take information from listening text and use it in various kinds of written or drawn completion exercises

f) Labeling. The students label diagrams picture to enable them to learn and remember the various part of a leaf or an engine

g) Using list. This activity consist of making list, offend a shopping list or a list of places to visit

h) True false. The students are provided with some statements to decide whether they true or false according to the listening text

i) Task completion gap filling. Where there are too many gaps to fill, it advisable to help students to impolite some before beginning to listen

j) Spotting mistake. The can use a clear picture in a book as the focus of the activity then talk about the picture, making some deliberate mistake and the students are required to indicate each time that they spot a mistake

k) Predicting. The presents the students an opportunity to speculate on what they might expect to hear in any given situation

1) Seeking specific items of information. The students seek out specific items and text the other parts pass

m) Listening cloze. Task (sometimes called cloze dictation or partial dictation) required the test-taker to listen to a story, monologue or conversation read the written text in which selected words or phrases have been deleted.

3) The post-listening stage

Post-listening activities are activities related to particular listening of text which are done after the listening is complete. Some post-listening activities are extensions of the work done at the pre-listening, while listening stage and some relate only loosely to the listening text itself. There are some activities that be used in the post-listening stage:

a) Form / chart completion. There often occasion on which the completion of form/chart of some section can only be done at more surely pace after listening

b) Extending lists. The students are ask to make a list or thick/check a list while listening and then to add to it after the listening is finished

c) Sequencing/grading. The students are requires to short out the various items as they listen and then to complete the activity after they have learned the whole passage/story

d) Extending note into written response. Brief notes made at the while listening stage can be extended into written text

e) Summarizing can done by extending notes made at the while listening stage or by simply depending on memory

f) Using information from the listening text for problem solves and decision making activities. The students can be ask to collect information from a listening text and apply the information to the solution of the problem or as a basic for a decision. 
g) Jig saw listening. The students are decided a small number of groups and each group listens to a different listening text, although all the text are on the same topic, and the groups exchange information to build up the complete story

h) Identifying relationship between speakers. can give the students notice by giving questions or two before listening

i) Establishing the mood/attitude/behavior of speakers. The listeners try to interpret what is said rather than just looking for the offered meaning. It is not just the words that are important but how they are spoken

j) Role play/simulation. The attraction of using listening as an input is that it can provide students with a selection of language appropriate to the roles and situation which are to be develop

k) Dictation. It is meant to get the students to concentrate on the listening text or parts of it; the emphasis is on spelling and writing English correct sentence but on the sorting out the meaning of the words spoken.

\section{c. Definition and steps in dictogloss}

Diane Tedick (2001) Dictogloss is a classroom dictation activity where learners are required to reconstruct a short text by listening and noting down key words, which are then used as a base for reconstruction.

Ruth Wajnryb (1990) is credited with developing a new way to do dictation, known as dictogloss. While there are many variations on dictogloss but, we will be describing five of these later in this thesis the basic formats are: First, The class engages in some discussion on the topic of the upcoming text. This topic is one on which students have some background knowledge and, hopefully, interest. The class may also discuss the text type of the text, e.g., narrative, procedure, or explanation, and the purpose, organizational structure, and language features of that text type. The second, the reads the text aloud once at normal speed as students listen but do not write. The text can be selected by s from newspapers, textbooks, etc., or s can write their own or modify an existing text. The text should be at or below students' current overall proficiency level, although there may be some new vocabulary. It may even be a text that students have seen before. The length of the text depends on students' proficiency level. The third, the reads or playing the text with the tape recorder at normal speed and students take notes. Students are not trying to write down every word spoken; they could not even if they tried, because the is reading at normal speed. Fourth, Students work in groups of two-four to reconstruct the text in full sentences, not in point form (also known as bullet points). This reconstruction seeks to retain the meaning and form of the original text but is not a word-for-word copy of the text read by the . Instead, students are working together to create a cohesive text with correct grammar and other features of the relevant text type, e.g., procedure, or rhetorical framework, e.g., cause and effect, that approximates the meaning of the original. And the last is Students, with the 's help, identify similarities and differences in terms of meaning and form between their text reconstructions and the original, which is displayed on an overhead projector or shown to students in another way. 
Dictogloss represents a major shift from traditional dictation. When implemented conscientiously, dictogloss embodies sound principles of language teaching which include: learner autonomy, cooperation among learners, curricular integration, and focus on meaning, diversity, thinking skills, alternative assessment, and $\mathrm{s}$ as co learners. These principles flow from an overall paradigm shift that has occurred in second language education (Jacobs \& Farrell, 2001). In this section, we discuss each of these five overlapping trends with reference to dictogloss. The Steps referred to below are the five steps in the standard dictogloss procedure described in the Introduction section above.

According to Azies Furqanul \& Alwasilah Chaedar (1996). In dictogloss technique there are four steps that should be pay attention, they are:

a. Preparing. In this step, the preparing students to listen the text and the give questions and discuss the stimulus, vocabulary, and make the students know about the material.

b. Dictation. In this step, the read the text twice. Firstly, the students only listen and get the general information from the text. The second, the students make note based on the text that they listen and then the students make a reconstruction. But, for consistence, it is better if the students listen the text from the tape recorder.

c. Reconstructions. In dictation ending, the students arrange the words become a text based on their listening.

d. Analysis and correction. In this section, the students can write their text in whiteboard or they can copy the text to their friends. After that the students can compare their text with the original text.

Based on the explanation above, the researcher concludes that dictogloss is an classic technique in dictation where the students can write the key words from their listening. And dictogloss take from two words, they are dictation and glossary. Dictation is a technique where the read or plays a text with tape recorder and the students write the key words and glossary is a key words or a group of difficult words.

\section{d. Teaching strategy of dictogloss}

George Jacobs and John Small (2003), teaching listening dictogloss technique the can combine with cooperative learning to make the students be interest and active in teaching and learning process. Cooperative learning, also known as collaborative learning is a body of concepts and techniques for helping to maximize the benefits of cooperation among students. There are eight cooperative learning principles and how they can inform the use of dictogloss.

1) Heterogeneous grouping. Forming groups in which students are mixed on one or more of a number of variables including sex, ethnicity, social class, religion, personality, age, language proficiency, and diligence is believed to have a number of benefits, such as encouraging peer tutoring, providing a variety of perspectives, helping students come to know and like others different from themselves, and fostering appreciation of the value of diversity. Thus, in forming groups for dictogloss, we might want to look at our class and 
make conscious decisions about which students should work together, rather than leaving the matter to chance or to students' choice.

2) Collaborative skills. Collaborative skills are those needed to work with others. Students may lack these skills, the language involved in using the skills, or the inclination to apply the skills during dictogloss.

3) Group autonomy. This principle encourages students to look to themselves for resources rather than relying solely on the .

4) Simultaneous interaction. In classrooms in which group activities are not used, the typical interaction pattern is that of sequential interaction, in which one person at a time - usually the - speaks. For example, the explains a point, asks a question to check students' comprehension of that point, calls on a student to answer the question, and evaluates that student's response. In traditional dictation, the is the only person who speaks, unless the calls on individual students to read back what has been dictated.

5) Equal participation (Kagan, 1994). A frequent problem in groups is that one or two group members dominate the group and, for whatever reason, impede the participation of others. Cooperative learning offers many techniques for promoting equal participation in groups. But, in this equal participation the students can take different notes from their listen so, Each person can have a role to play.

6) Individual accountability. Individual accountability is, in some ways, the flip side of equal participation. When we try to encourage equal participation in groups, we want everyone to feel they have opportunities to take part in the group.

7) Interdependence. This principle lies at the heart of cooperative learning. When positive interdependence exists among members of a group, they feel that what helps one member of the group helps the other members and that what hurts one member of the group hurts the other members.

8) Cooperation as a value. This principle means that rather than cooperation being only a way to learn, i.e., the how of learning, cooperation also becomes part of the content to be learned.

Based on the explanations above the researcher conclude that, teaching dictogloss in listening can collaborate with the cooperative learning to make the students be active and work together but each students in group can work or write the words that they listen alone. And then, each student can compare the words that they write with their friends in group to complete one and another.

\section{e. The purposes of dictogloss technique}

Miguel (2008) there some purposes of the dictogloss technique in teaching English, the first is introduce key words and target lexical items at the beginning of a work sequence or task. Second is encouraging learners to focus on meaning when listening to spoken text. Third is develop effective first-time listening strategies and to provide relevant listening practice. Forth is develop proof reading and editing skills and strategies. Fifth is providing an authentic opportunity for cooperative learning. And the last is assisting weaker learners and learners who require significant support with reading and writing activities. 
Beside that, Miguel also give some ways to carry our dictogloss, the ways are: Divided the students into small group, A text read to students in normal speed, Ask the learners to write down the key words and lexical items that they hear as the text is read aloud, Working in small groups, the students pool their notes and attempt to reconstruct a version of the text from their shared resources that contains the main ideas of the text and approximates the generic staging and language choices of the passage, Require the groups to proof read and edit their texts before presenting them to the class either in oral or written form, And then require the groups to compare their texts with the original text in order to justify the differences between them.

In the same way, Miguel also gives some alternatives that can be combine with the ways above, the alternatives are: Have students write their version of the text on the board. If for example, students are working in four groups, divide the board into four columns and ask one student from each group to enter her version of the text down one column. This allows the students and to draw on all four versions to decide on the best final text. And another alternative is alternatively OHTs can be used (one per group). It is useful for the to prepare for this phase of the lesson by considering the most important language features of the text, so as to be prepared to focus on them with the students.

\section{f. The Advantage of Dictogloss Technique}

Zorana Vasiljevic in Journal English Langauge Teaching (2010) explain that the the dictogloss model offers several potential advantages over other models of teaching listening comprehension. They are ; First, the dictogloss method is an effective way of combining individual and group activities. Students listen and takenotes individually and then work together to reconstruct the texts. The reconstruction task gives students focus and aclear objective, which is a precondition for effective groupwork. Students are actively involved in the learning process and there are multiple opportunities for peer learning and peer teaching. After the provides a framework for understanding the passage by explaining the background information, cooperative groups can develop more appropriate comparisons or examples that will assist learners with their comprehension (Thornton, 1999). Second, the dictogloss procedure facilitates the development of the learners' communicative competence. Students' speaking time is significantly longer than in a traditional -centered classroom. At the same time, the pressure to reconstruct the text within the time limit also means that students are more likely to use time effectively. Furthermore, unlike in a typical discussion class where students are presented with a list of topics or discussion questions and communication activities often have a simple question-and-answer format, in a dictogloss class, students' interaction is much more natural. A collaborative reconstruction task gives learners the opportunities to practice and use all modes of language and to become engaged in authentic communication. There is more turn-taking and students are more likely to use confirmation and clarification strategies. The variety of interaction was found to be more productive in terms of language development than the actual linguistic forms used (Wills \& Wills, 1996). As Long and Robinson (1998) point out, people learn languages best not by 
treating them as an object of study, but by experiencing them as a medium of communication. Third, the reconstruction stage helps students try out their hypotheses and subsequently to identify their strengths and weaknesses. A reconstruction task encourages students to consider the input more closely. Noticing is known to be one of the crucial elements of the language learning process (Ellis, 1995). The reconstruction and correction stages help the students to compare input to their own representation of the text and to identify the possible gaps. It is through this process of cognitive comparison that new forms are incorporated, students' language competence improves and students' inter language is restructured.

\section{g. The Disadvantage of Dictogloss Technique}

From the explanation above, the researcher conclude that, the disadvantage of dictogloss technique is the will need long time to do all of dictogloss procedure technique because the dictogloss technique have a similar wit spot dictogloss technique. And in another hand Fitri Wulandari (2011), he said that to do the spot dictogloss technique a need long time to pass all of the procedures.

\section{METHODOLOGY}

This research was a pre-experimental research, which employed one-group pretest-posttest. This research was conducted through three steps of process: pretest, treatment and post-test. Pretest was done to measure the students reading comprehension before conducting the treatment. The treatment, which was the teaching and learning process, was conducted in four meetings in which Dictogloss Technique was applied as method to improve the students listening comprehension. After the treatment, post-test was done to measure the students reading comprehension after the implementation of Dictogloss Technique. Location of this research is Second Semester Students of Accounting Department in Economic Faculty of University Muhammadiyah of Parepare in 2013/2014 academic years. The total numbers of subjects were 160 students, which were divided into 2 groups there were experimental group and control group. In testing the hypothesis, t-test was employed. The calculation was done by using SPSS v.16.

\section{FINDINGS \& DISCUSSION}

To describe whether the use of the dictogloss is able to increase students' listening comprehension. In teaching and learning process the Lecturer did some process, such as: The Lecturer introduced and gave explanation about what is the dictogloss and how to learn by using dictogloss technique. After that, the students were classified in some groups to listen the text from the tape recorder and the Lecturer gave instruction about the task. Here, the Lecturer tells about the dictogloss in teaching and learning process and gave to the students general describing about the story. In this stage, the Lecturer also gave some words about the text to the students. But, before listen the text, the Lecturer gave a chance to remember and said the words that explain before. In the next section, the Lecturer gave the worksheet to the students and they analyzed the text. Then, the students 
listened the text from tape recorder in three times and the Lecturer walk around to check and control the students' activities, in the first time they only listen the text. In the second time, the students could write the sentences as basic to complete the text. And in the third times the students completed the text. But, in this time $60 \%$ students could complete the text and some of them could not write the sentences in the right way. So, the Lecturer initiated to read the text once again and $85 \%$ students can complete the text in right way.

The Lecturer before closing the teaching and learning process, he asked the difficulties that students found during the listening process. Some of the students said that there some new words for them. So, to solve this problem the Lecturer gave advices like the students should study more about new words and read kind English books or references because from its they could got more new words and informatios. Finally, the Lecturer gave conclusion about the material.

1. The rate percentage of the students score through pre-test and Post Test of Experimental Class

The result of pre-test of the experimental class of Second Semester Students of Accounting Department in Economic Faculty of University Muhammadiyah of Parepare in 2013/2014 academic years are tabulated as follows:

Table 1. The Frequency and Percentage of The Score of Post - Test in Experimental Class

\begin{tabular}{|c|c|c|c|c|c|}
\hline \multirow{3}{*}{ Classification } & \multirow{3}{*}{ Score } & \multicolumn{2}{|c|}{ Frequency } & \multicolumn{2}{|c|}{ Percentage } \\
\hline & & \multicolumn{4}{|c|}{ Experimental Class } \\
\hline & & Pre & $\begin{array}{l}\text { Post } \\
\text { test }\end{array}$ & Pre & Post \\
\hline Very good & $85-100$ & - & 14 & 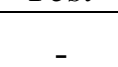 & $17.5 \%$ \\
\hline Good & $70-84$ & 60 & 66 & $75 \%$ & $82.5 \%$ \\
\hline Fair & $55-69$ & 20 & - & $25 \%$ & - \\
\hline Poor & $50-54$ & - & - & - & - \\
\hline Very poor & $0<45$ & - & - & _ & - \\
\hline Total & & 80 & 80 & $100 \%$ & $100 \%$ \\
\hline
\end{tabular}

2. The rate percentage of the students score through of post-test

The result of post - test of control class of the students on listening comprehension is presented in table below: 
Table 2. The Frequency and Percentage of The Score of Post - Test in Control Class

\begin{tabular}{|c|c|c|c|c|c|}
\hline \multirow{3}{*}{ Classification } & \multirow{3}{*}{ Score } & \multicolumn{2}{|c|}{ Frequency } & \multicolumn{2}{|c|}{ Percentage } \\
\hline & & \multicolumn{3}{|c|}{ Control Class } & \multirow[b]{2}{*}{$\begin{array}{c}\text { Post } \\
\text { test }\end{array}$} \\
\hline & & $\begin{array}{l}\text { Pre } \\
\text { Test }\end{array}$ & $\begin{array}{c}\text { Post } \\
\text { test }\end{array}$ & $\begin{array}{l}\text { Pre } \\
\text { Test }\end{array}$ & \\
\hline Very good & $85-100$ & - & 4 & - & $5 \%$ \\
\hline Good & $70-84$ & 64 & 76 & $80 \%$ & $95 \%$ \\
\hline Fair & $55-69$ & 16 & - & $20 \%$ & - \\
\hline Poor & $50-54$ & - & - & - & - \\
\hline Very poor & $0<45$ & - & - & - & - \\
\hline Total & & 80 & 80 & $100 \%$ & $100 \%$ \\
\hline
\end{tabular}

3. The Mean Score and Standard Deviation of Pre-Test and Post-Test

After calculating the result of the students pre-test, the mean scores and the deviation are presented in table 3 :

Table 3. The Mean Score and Standard Deviation of The Students

\begin{tabular}{|c|c|c|c|c|c|}
\hline \multirow[b]{3}{*}{ No } & \multirow[b]{3}{*}{ Variables } & \multicolumn{4}{|c|}{ Mean scores } \\
\hline & & Pre & & Post & \\
\hline & & Test & Classification & Test & Classification \\
\hline 1 & $\begin{array}{l}\text { Experimental } \\
\text { Class }\end{array}$ & 69.5 & Fair & 75.88 & Good \\
\hline 2 & Control Class & 69.69 & Fair & 72.88 & Good \\
\hline
\end{tabular}

4. The Standard Deviation of The Students'Pre-Test and Post-Test

Table 4. The Standard Deviation of the Students' Pre-test and Post-test

\begin{tabular}{rcc}
\hline \multirow{2}{*}{ Test } & \multicolumn{2}{c}{ Standard Deviation } \\
\cline { 2 - 3 } & Experimental group & Control Group \\
\hline Pre-test & 6.45 & 4.35 \\
Post-test & 7.28 & 5.23 \\
\hline
\end{tabular}


5. The t- test of Students' Listening Comprehension in Experimental and Control Class

Table 5. Students' T-Test of Experimental and Control Class

\begin{tabular}{ccc}
\hline \multirow{2}{*}{ T Table Value } & \multicolumn{2}{c}{ T Test } \\
\cline { 2 - 3 } & Pre Test & Post Test \\
\hline 1.660 & 0.55 & 2.97 \\
\hline
\end{tabular}

During the process, the researcher found that the students in this department needed the creative strategies in teaching and learning process to improve their ability because some of them still confuced and borried. To reduced this condition the researcher needed to collaborated and classified the students into some groups heteregenous. Based on dictogloss concept, the students must be in heteregenous group to reduce the dominance of the smart students. Throught this method, the researcer formulted the students to learn together step by step such as the researcher in the first step gave introduction about the materials after that the researcher explaration. In this phase provides an opportunity for students to reveal knowledge initially, develop new knowledge, and to explain phenomena they experienced with minimal teacher guidance.

This leads to cognitive conflict on them and try to do the testing and discussion to explain the observations. Basically, the purpose of this phase is to generate interest, curiosity and preconceptions of students applying to the learning activities by starting from the concrete. During this process students learn through their own actions and reactions in a new situation that is still in touch, also proved to be very effective for herding students designing experiments, demonstrations.

Looking at the result of t-test statistical analysis at the level of significance 0.05 with the degree of freedom (Df) $(n 1+n 2-2)=158$. The researcher found that $2.97>1.660$. It is concluded that there was different between the students' t-test value than t-table value. The mean score of the student's pre-test for the experimental group was 69.5 and control group was 69.69 and the mean scores of post-test for the experimental group was 75.88 and control groups was 72.88 . It means that the student's mean scores of pre-test and post-test were statistically different. It's cause of most of the students interested in the dictogloss technique to teach listening comprehension.

The result of the discussion above indicates that the alternative hypothesis is accepted and the null hypothesis is rejected. In other words, the dictogloss technique could improve the students' listening comprehension. From the data alaysis also show that the students Post Test score in Experimental Class was high than the students in Control Class. 


\section{CONCLUSION}

Based on the data which have analyzed by using $t$ - test statistical procedures, the result of the analysis shows that there is significant increase from the pre - test to the post - test in listening comprehension achievement of the students after taught with dictogloss technique. It proved with the result of the pre test and post test for level of significance $(\alpha=0.05)$, the post test was high than pre test. It means that, the use of dictogloss in teaching listening comprehension is effective to improve the students' listening comprehension to the Second Semester Students of Accounting Department in Economic Faculty of University Muhammadiyah of Parepare.

\section{REFERENCE}

Abbas, Hasriani. (2003). Teaching Listening Using Audio Tape Recording to The Third years Students of SLTP Negeri 4 Parepare. Unpublished thesis. Parepare: FKIP UMPAR

Ardiana. (2008). Improving listening Ability of the Second Years Students of SMP Negeri 2 Suppa through English Songs Using Varied Exercise. Unpublished thesis. Parepare: FKIP UMPAR

Azis, Furqanul \& Alwasilah Chaedar. (1996). Pengajaran Komunikatif. Bandung: PT Remaja Rosdakarya.

Diane Tedick. (2001). Article : Dictogloss Procedure. (Online). www2.klett.de/sixcms/media. Accesed on $22^{\text {nd }}$ January 2014.

Departemen Pendidikan Nasional. (2005). Peraturan Direktorat Jenderal Pendidikan Dasar dan Menengah tentang Penilaian Perkembangan Peserta Didik. Jakarta : Dinas Pendidikan Repoblik Indonesia.

Endang. (2003). Using English Song to Increase the Listening Ability Of the Third Years Students of SMU Negeri 4 Parepare. Unpublished thesis. Parepare: FKIP UMPAR.

Eneida Gomes Nalini de Oliveira. (2012). Journal Doutoranda em Linguística : Dictogloss. (Online). Vol. 8, No. 2, (www.nus.edu.sg., Accesses on $22^{\text {nd }}$ January 2014).

Fansury, A. H., Lutfin, N., \& Arsyad, S. N. (2019). Audio Books as Teaching Media to Blind Students in Learning EFL. Klasikal: Journal of Education, Language Teaching and Science, 1(1), 1-9.

Fitri Wulandari. (2011). Thesis : Dictogloss as an Interactive Method of Teaching Listening Comprehension to L2 Learners. Unpublished Thesis. Surakarta:Universitas Sebelas Maret.

Faharuddin, Gaffar. (2009). Improving Listening Ability Of The Second Year Students of SMP Negeri 2 Suppa through English Songs.

Gay, L. R. (1981). Educational Research: Compotencies for Analysis and Application: Second Edition. Columbus, Ohio: Charles E. Merrill Publishing Company.

George, Jacobs. Combining dictogloss and cooperative learning to Promote language learning. Online at http://www.clcrc.com/pages/qanda.html. Retrivied on March 20, 2010. 
Indah, Nur. (2003). Improving the Listening Comprehension of the Third Grade Students of SLTP Negeri 1 Parepare Through Translating English Songs. Unpublished thesis. Parepare: FKIP UMPAR.

Kairyudo. Journal: The Value of Dictogloss for Japanese Senior High School Students,(online). www.kairyudo.co.jp accessed on 22nd Januari 2014.

Kowal, M. \& Swain, M. (1997). From semantic to syntactic processing: How Can WE promote it in the immersion classroom? in $r$. johnson \& m. swain (eds.) immersion education: international perspectives (pp. 284-309). NY: Cambridge University Press.

Saricoban, Arif. (1999). The Teaching of Listening. Online at http//www.ncler.org/essential/listening index. Retrieved on March 15, $\underline{2010}$

Soehardjo, (2000). Teaching English As A Foreign Language. Unpublished Modul. Parepare, FKIP. UMPAR

Sugiyono. (2007). Statistika Untuk Penelitian. Alfabeta. Bandung.

Swain, M. (1995). Three Functions of Output in Second Language Learning. In G. Cook \& B. Seidlhofer (Eds.) Principle and Practice in Applied Linguistics (pp. 125-144). Oxford: Oxford University Press.

Swain, M. (1998). Focus on Form Through Conscious Reflection. In c. Doughty $\&$ j. Williams (eds.), Focus on Form in Classroom Second Language Acquisition (pp. 64-81). New York, NY: Cambridge University Press.

Tim Penyusun Pedoman Akademik. (2011). Pedoman Akademik UMPAR. Unpublished Book. UMPAR.

Wajnryb, R. (1990). Grammar dictation. Oxford: Oxford University Press.

Zorana Vasiljevic. (2010). Journal English Language Teaching : Dictogloss as an Interactive Method of Teaching Listening Comprehension to L2 Learners, (online), Vol. 3. No.1, (http//:www.ccsenet.org/elt). Accesed on $22^{\text {nd }}$ January 2014 